\title{
HEPATOPROTECTIVE EFFECT OF DEFERASIROX IN CONCANAVALIN A-INDUCED ACUTE LIVER INJURY IN RATS
}

\section{BY}

\author{
Nada Adel ${ }^{\text {a }}$, Eman M. Mantawy ${ }^{\text {a }}$, Doaa El-Sherbiny ${ }^{\text {a }}$, Ebtehal El-Demerdash ${ }^{\text {a }}$ \\ FROM \\ a: Department of Pharmacology \& Toxicology, Faculty of Pharmacy, Ain Shams \\ University, Cairo, Egypt
}

\begin{abstract}
Hepatitis poses a significant health issue worldwide as it may progress to cirrhosis and hepatocellular carcinoma. The crucial role of liver in different metabolic and synthetic functions of the body stimulates researchers to continually explore and develop different hepatoprotective drugs. The present study was designed to assess the potential hepatoprotective effect of deferasirox (DFX) in a rat model of acute liver injury induced by concanavalin A (Con A) at a dose of $20 \mathrm{mg} / \mathrm{kg}$ intravenously dissolved in normal saline solution. The hepatoprotective effect of DFX was screened at the doses $(25,50$, and $100 \mathrm{mg} / \mathrm{kg}$ ) via assessing the hepatotoxicity indices and histopathological examination. DFX at a dose of $100 \mathrm{mg} / \mathrm{kg}$ was the most effective in preventing the rise in activities of hepatotoxicity serum markers; alanine aminotransferase (ALT), and aspartate aminotransferase (AST) enzymes and histopathologic changes induced by con $\mathrm{A}$.
\end{abstract}

Keywords: Deferasirox; Concanavalin A; Hepatoprotective; Liver injury.

\section{INTRODUCTION}

Liver diseases represent a critical public health problem globally because of the significant morbidity and mortality associated with it, which negatively affects the quality of life of the individuals.

Concanavalin A (Con A)-induced liver injury is the most reliable animal model available nowadays for the study of viral and autoimmune hepatitis. Con A injection in rats results in the apoptosis and necrosis of hepatocytes with the subsequent release of one of the very specific markers for liver damage, alanine transaminase (ALT) (Yin et al., 2010). Acute liver injury induced by con $A$ also depends on the activation of both adaptive and innate immune responses, specifically $\mathrm{CD} 4^{+} \mathrm{T}$-cells and natural killer cells (Tiegs et al., 1992), and thus it can resemble the immunologically-mediated liver damage in humans.

Deferasirox (DFX) is an orally-active, tri-dentate iron chelator that is used to treat iron overload conditions caused by repeated blood transfusions or genetic blood disorders in children and adults (Lindsey and Olin, 2007; Nisbet-Brown et al., 2003) that was clinically proved to be well tolerated in patients (Nisbet-Brown et al., 2003). 
Deferoxamine has been the iron chelator of choice since the 1970s (Neufeld, 2006), but the requirement for subcutaneous infusion of deferoxamine over 8 to 12 hours, 5 to 7 days a week and its associated side effects made it less compliant for patients (Cappellini, 2005; Modell et al., 2000; Olivieri and Brittenham, 1997). DFX showed anti-inflammatory, anti-oxidant, and hepatoprotective and cardioprotective effects in previous studies (Al-Rousan et al., 2011, 2009; Messa et al., 2010) which make it a promising candidate in our study.

In the present study, we aimed to investigate the potential hepatoprotective effect of DFX at three different doses; 25, 50, and $100 \mathrm{mg} / \mathrm{kg}$ in concanavalin A-induced acute liver injury in rats.

\section{MATERIALS AND METHODS}

\subsection{Materials}

Deferasirox was purchased from Royal Pharms Co. (China). It was dissolved in a mixture of $10 \%$ DMSO in corn oil at concentration $(25 \mathrm{mg} / \mathrm{ml})$. Concanavalin A was purchased from Sigma-Aldrich Co. (St. Louis, MO, USA), and was dissolved in normal saline solution at concentration $(10 \mathrm{mg} / \mathrm{ml})$. All other chemicals and solvents were of highest grade commercially available.

\subsection{Animals and experimental protocol}

The study design was approved by the Ethics Committee of Faculty of Pharmacy, Ain Shams University, Egypt. Male Wistar rats weighing 150-200 g were used. They were kept in the animal house facility in air-conditioned atmosphere and were provided with rodent chow and water ad libitum. Diet pellets contained not less than $20 \%$ protein, $5 \%$ fiber, $3.5 \%$ fat, $6.5 \%$ ash, and a vitamin mixture).

Fifty rats were randomly divided into five different groups (10 rats/group); Group A was considered the control rats receiving the vehicle only once. Group B was the disease group where rats received single intravenous injection of Con A (20 mg/kg). Groups C, D, E received a single dose of DFX orally $(25,50,100 \mathrm{mg} / \mathrm{kg}$, respectively) followed by single intravenous injection of Con A $(20 \mathrm{mg} / \mathrm{kg}) 2$ hours later.

Twenty-four hours after Con A injection, blood samples were collected from the retro-orbital plexus and allowed to clot. Serum was separated by centrifugation of blood at $4000 \mathrm{rpm}$ for 15 minutes at $4{ }^{\circ} \mathrm{C}$ then stored at $-20{ }^{\circ} \mathrm{C}$ for further biochemical analyses. The rats were then sacrificed, liver tissues were dissected and washed with ice-cold saline. Tissue sections were fixed in $10 \%$ formalin for histopathological analysis. 


\subsection{Assessment of hepatotoxicity indices}

The activities of alanine aminotransferase (ALT) and aspartate aminotransferase (AST) enzymes were measured colorimetrically in serum using commercially-available kits (Spectrum Diagnostics, Cairo, Egypt) according to the manufacturer's instructions.

\subsection{Histopathological examination}

Liver specimens were fixed in $10 \%$ formalin, and embedded in paraffin blocks. Sections of $4 \mu \mathrm{m}$ thickness were cut and stained using hematoxylin and eosin (H \& E) stain and examined using light microscope.

\subsection{Statistical analysis}

Data are presented as mean \pm SD. Statistical analysis was performed using oneway analysis of variance (ANOVA) followed by Tukey-Kramer as a post hoc test. The 0.05 level of probability was used as the criterion for significance. All statistical analyses were performed using Instat software package (version 3.06). Graphs were sketched using GraphPad Prism (ISI ${ }^{\circledR}$ software, USA) version 5.0.

\section{RESULTS}

\subsection{Effect of DFX on hepatotoxicity indices:}

Con A administration induced a significant increase in ALT and AST activities by $111 \%$ and $33 \%$ respectively as compared to the control group. Pretreatment with DFX at a dose of $25 \mathrm{mg} / \mathrm{kg}$ did not show any significant difference in ALT and AST levels as compared to Con A group. DFX at a dose of $50 \mathrm{mg} / \mathrm{kg}$ showed a significant decrease in ALT level by $30 \%$ but no significant decrease in AST level as compared to Con A group. Only DFX at the dose $100 \mathrm{mg} / \mathrm{kg}$ was able to significantly decrease both ALT and AST levels by $29 \%$ as compared to Con A group (Table 1).

Table 1. Effect of different doses of Deferasirox on serum ALT and AST levels.

\begin{tabular}{|c|c|c|}
\hline Groups & ALT (U/L) & AST (U/L) \\
\hline Control & $11.59 \pm 4.1^{\mathrm{b}}$ & $66.84 \pm 1.11^{\mathrm{b}}$ \\
\hline Con A & $24.43 \pm 4.93^{\mathrm{a}}$ & $88.63 \pm 15.89^{\mathrm{a}}$ \\
\hline Con A + DFX $(\mathbf{2 5} \mathbf{~ m g / k g )}$ & $22.85 \pm 4.2^{\mathrm{a}}$ & $73.36 \pm 16.28$ \\
\hline Con A + DFX $(\mathbf{5 0} \mathbf{~ m g / k g )}$ & $17.03 \pm 3.03^{\mathrm{b}}$ & $79.05 \pm 5.21$ \\
\hline Con A + DFX $(\mathbf{1 0 0} \mathbf{~} \mathbf{~ g /} / \mathbf{k g})$ & $17.25 \pm 2.7^{\mathrm{b}}$ & $62.53 \pm 6.4^{\mathrm{b}}$ \\
\hline
\end{tabular}

Data are represented as mean \pm S.D. $(n=10)$. a or $b$ : significantly different from the control or con A group respectively at P-value $<0.05$ using ANOVA followed by

Tukey-Kramer multiple comparisons test as post-hoc test.

\subsection{Histopathological examination:}

Liver sections from control rats showed no histopathological alteration with normal histological structure of the central vein and surrounding hepatocytes in the 
hepatic parenchyma (Fig. 1A). Con A group showed severe congestion in both central and portal veins associated with degeneration in the adjacent surrounding hepatocytes as well as inflammatory cells infiltration in the portal area (Fig. 1B). Pretreatment of intoxicated rats with DFX at the doses $25 \mathrm{mg} / \mathrm{kg}$ and $50 \mathrm{mg} / \mathrm{kg}$ DFX still showed dilatation and some congestion in the central and portal veins associated with inflammatory cell infiltration in the portal area (Fig. 1C, 1D). On the other hand, pretreatment of intoxicated rats with DFX at a dose of $100 \mathrm{mg} / \mathrm{kg}$ could almost restore the normal hepatic architecture (Fig. 1E). Scoring of these histopathological findings was done by a histopathologist (Table 2).

Table 2. Histopathological grading

\begin{tabular}{|l|l|l|l|}
\hline \multirow{2}{*}{ Groups } & \multicolumn{2}{|l|}{ Histopathological Alteration } \\
\cline { 2 - 4 } & $\begin{array}{l}\text { Centrilobular } \\
\text { necrosis }\end{array}$ & $\begin{array}{l}\text { Ballooning } \\
\text { degeneration }\end{array}$ & Dilatation of central vein \\
\hline Control & - & - & +++ \\
\hline Con A & +++ & +++ & ++ \\
\hline $\begin{array}{l}\text { Con A+ DFX } \\
(25 \mathrm{mg} / \mathrm{kg})\end{array}$ & +++ & ++ & ++ \\
\hline $\begin{array}{l}\text { Con A+ DFX } \\
(50 \mathrm{mg} / \mathrm{kg})\end{array}$ & ++ & ++ & - \\
\hline $\begin{array}{l}\text { Con A+ DFX } \\
(100 \mathrm{mg} / \mathrm{kg})\end{array}$ & - & - & \\
\hline
\end{tabular}




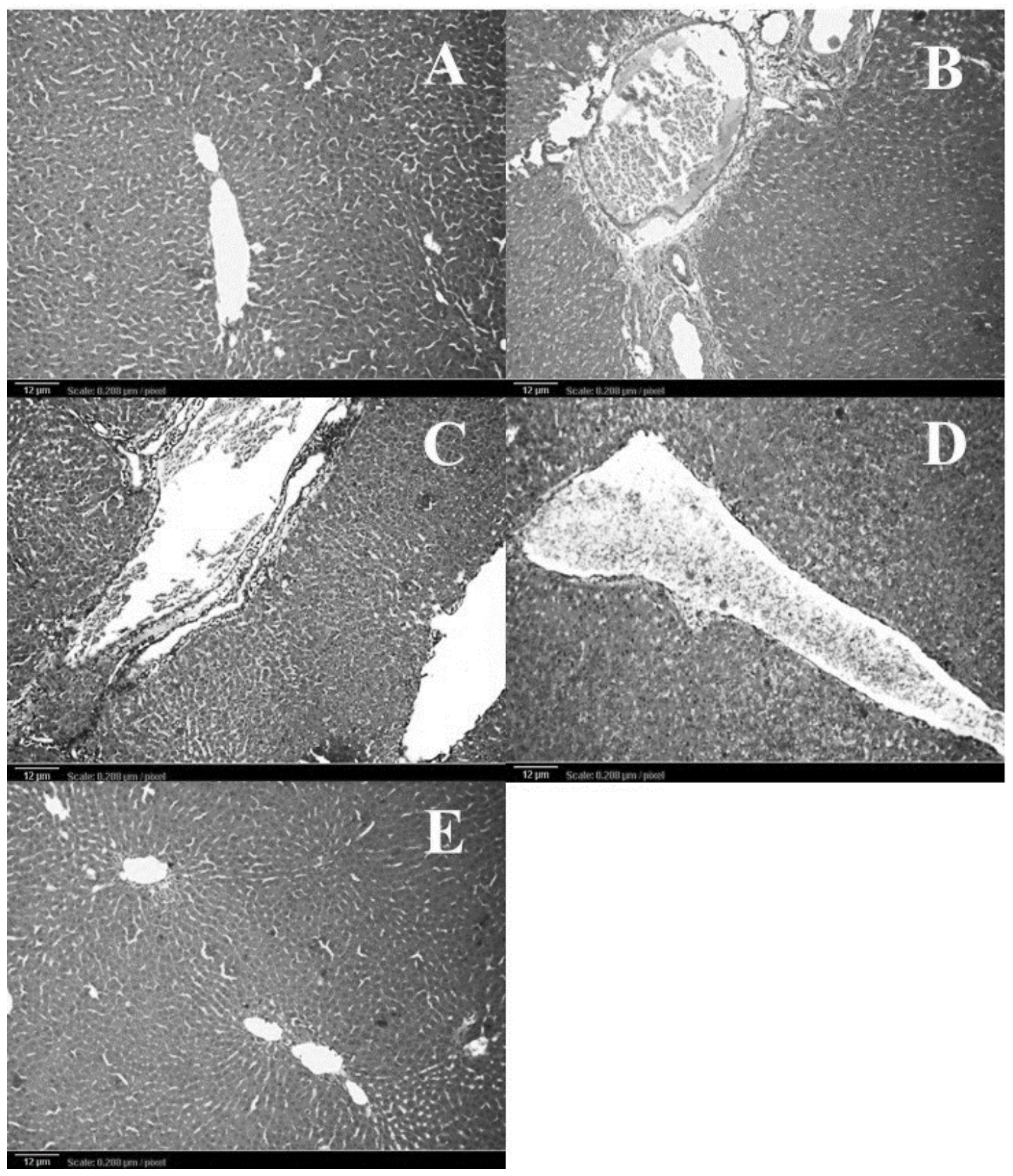

Figure 1. Histopathological analysis of rat liver sections using $H \& E(\times 100)$. (A): Control group, (B): Con A-treated group, (C): Group pretreated with $25 \mathrm{mg} / \mathrm{kg}$ DFX, (D): Group pretreated with $50 \mathrm{mg} / \mathrm{kg}$ DFX, (E): Group pretreated with $100 \mathrm{mg} / \mathrm{kg}$ DFX.

\section{DISCUSSION}

Hepatitis is a growing problem worldwide, occurring due to different etiological factors including viral hepatitis, auto-immune hepatitis, and alcoholic liver disease that may progress to acute liver failure. The crucial role of liver in different metabolic and synthetic functions of the body stimulates researchers to continually explore and develop different hepatoprotective drugs (Xie et al., 2015). 
Con $\mathrm{A}$ is a bean-derived lectin, that induces liver injury in mice mediated by the activated $\mathrm{CD} 4^{+} \mathrm{T}$-cells (Tiegs et al., 1992). Con A binds to sinusoidal endothelial cells and kupffer cells, activating $\mathrm{CD} 4^{+} \mathrm{T}$-cells and stimulating the release of tumor necrosis factor alpha (TNF- $\alpha)$, interferon gamma (IFN- $\gamma$ ), and other inflammatory cytokines (Knolle et al., 1996; Schümann et al., 2000). Thus, con A model of T-cell mediated liver injury can resemble auto-immune hepatitis, viral hepatitis, and the related acute liver failure (Tsutsui and Nishiguchi, 2014; Wang et al., 2012).

The current study investigated the potential hepatoprotective effect of DFX against con A-induced acute hepatotoxicity. In our study, intravenous injection of Con A in rats caused a significant increase in serum ALT and AST enzymes' activities as compared to the control group. These enzymes are released from hepatocytes into circulation upon hepatocellular injury leading to an increase in their serum activities indicating loss of cell membrane integrity and cellular leakage (Rajesh and Latha, 2004). These findings were further confirmed by the histopathological examination where con A intoxication caused severe congestion, hepatocyte degeneration, and inflammatory cell infiltration. DFX at the doses $25 \mathrm{mg} / \mathrm{kg}$ and $50 \mathrm{mg} / \mathrm{kg}$ slightly reduced the activities of both ALT and AST enzymes but with no statistical significance and failed to prevent the histopathological damage to the liver tissue as shown by the presence of marked congestion and inflammatory cell infiltration caused by con A intoxication. On the other hand, DFX pre-treatment at the dose $100 \mathrm{mg} / \mathrm{kg}$ significantly reduced the activities of both ALT and AST enzymes. Additionally, it showed protection against Con A-induced histopathological alterations as evidenced by the restoration of the normal hepatic architecture except for few inflammatory cell infiltrations in the portal area. In agreement with our findings, the hepatoprotective effect of another iron chelator; deferoxamine was previously reported against endotoxemia-induced and carbon tetrachloride-induced liver injury (Cermanova et al., 2014; Mohammed et al., 2016).

Based on the aforementioned biochemical analysis and histopathological examination, the most hepatoprotective effect was observed at the $100 \mathrm{mg} / \mathrm{kg}$ dose of deferasirox. In conclusion, our results revealed for the first time the potential hepatoprotective effect of DFX against con A-induced acute liver injury.

\section{REFERENCES}

Al-Rousan, R.M., Paturi, S., Laurino, J.P., Kakarla, S.K., Gutta, A.K., Walker, E.M., Blough, E.R., 2009. Deferasirox removes cardiac iron and attenuates oxidative stress in the iron-overloaded gerbil. Am. J. Hematol. 84, 565-570. doi:10.1002/ajh.21487

Al-Rousan, R.M., Rice, K.M., Katta, A., Laurino, J., Walker, E.M., Wu, M., Triest,
W.E., Blough, E.R., 2011. Deferasirox protects against iron-induced hepatic
injury in Mongolian gerbil. Transl. Res. 157, 368-377. 
doi:10.1016/j.trsl.2010.12.007

Cappellini, M.D., 2005. Overcoming the challenge of patient compliance with iron chelation therapy. Semin. Hematol. 42, S19-21.

Cermanova, J., Kadova, Z., Dolezelova, E., Zagorova, M., Safka, V., Hroch, M., Laho, T., Holeckova, M., Mokry, J., Kovarikova, P., Bures, J., Sterba, M., Micuda, S., 2014. Deferoxamine but not Dexrazoxane Alleviates Liver Injury Induced by Endotoxemia in Rats. Shock 42, 372-379. doi:10.1097/SHK.0000000000000210

Knolle, P.A., Gerken, G., Löser, E., Dienes, H.P., Gantner, F., Tiegs, G., Meyer zum Büschenfelde, K., Lohse, A.W., 1996. Role of sinusoidal endothelial cells of the liver in concanavalin A-induced hepatic injury in mice. Hepatology 24, 824-829. doi:10.1002/hep.510240413

Lindsey, W.T., Olin, B.R., 2007. Deferasirox for Transfusion-Related Iron Overload: A Clinical Review. Clin. Ther. 29, 2154-2166. doi:10.1016/j.clinthera.2007.10.015

Messa, E., Carturan, S., Maffe, C., Pautasso, M., Bracco, E., Roetto, A., Messa, F., Arruga, F., Defilippi, I., Rosso, V., Zanone, C., Rotolo, A., Greco, E., Pellegrino, R.M., Alberti, D., Saglio, G., Cilloni, D., 2010. Deferasirox is a powerful NF- B inhibitor in myelodysplastic cells and in leukemia cell lines acting independently from cell iron deprivation by chelation and reactive oxygen species scavenging. Haematologica 95, 1308-1316. doi:10.3324/haematol.2009.016824

Modell, B., Khan, M., Darlison, M., 2000. Survival in $\beta$-thalassaemia major in the UK: data from the UK Thalassaemia Register. Lancet 355, 2051-2052. doi:10.1016/S0140-6736(00)02357-6

Mohammed, A., Abd Al Haleem, E.N., El-Bakly, W.M., El-Demerdash, E., 2016. Deferoxamine alleviates liver fibrosis induced by $\mathrm{CCl}_{4}$ in rats. Clin. Exp. Pharmacol. Physiol. 43, 760-768. doi:10.1111/1440-1681.12591

Neufeld, E.J., 2006. Oral chelators deferasirox and deferiprone for transfusional iron overload in thalassemia major: new data, new questions. Blood 107, 34363441. doi:10.1182/blood-2006-02-002394

Nisbet-Brown, E., Olivieri, N.F., Giardina, P.J., Grady, R.W., Neufeld, E.J., Séchaud, R., Krebs-Brown, A.J., Anderson, J.R., Alberti, D., Sizer, K.C., Nathan, D.G., 2003. Effectiveness and safety of ICL670 in iron-loaded patients with thalassaemia: a randomised, double-blind, placebo-controlled, 
dose-escalation trial. Lancet 361, 1597-1602. doi:10.1016/S01406736(03)13309-0

Olivieri, N.F., Brittenham, G.M., 1997. Iron-chelating therapy and the treatment of thalassemia. Blood 89, 739-61.

Rajesh, M.., Latha, M.., 2004. Preliminary evaluation of the antihepatotoxic activity of Kamilari, a polyherbal formulation. J. Ethnopharmacol. 91, 99-104. doi:10.1016/j.jep.2003.12.011

Schümann, J., Wolf, D., Pahl, A., Brune, K., Papadopoulos, T., van Rooijen, N., Tiegs, G., 2000. Importance of Kupffer Cells for T-Cell-Dependent Liver Injury in Mice. Am. J. Pathol. 157, 1671-1683. doi:10.1016/S00029440(10)64804-3

Tiegs, G., Hentschel, J., Wendel, A., 1992. A T cell-dependent experimental liver injury in mice inducible by concanavalin A. J. Clin. Invest. 90, 196-203. doi:10.1172/JCI115836

Tsutsui, H., Nishiguchi, S., 2014. Importance of Kupffer Cells in the Development of Acute Liver Injuries in Mice. Int. J. Mol. Sci. 15, 7711-7730. doi:10.3390/ijms15057711

Wang, H.-X., Liu, M., Weng, S.-Y., Li, J.-J., Xie, C., He, H.-L., Guan, W., Yuan, Y.-S., Gao, J., 2012. Immune mechanisms of Concanavalin A model of autoimmune hepatitis. World J. Gastroenterol. 18, 119-25. doi:10.3748/wjg.v18.i2.119

Xie, J., Liu, J., Chen, T.-M., Lan, Q., Zhang, Q.-Y., Liu, B., Dai, D., Zhang, W.-D., Hu, L.-P., Zhu, R.-Z., 2015. Dihydromyricetin alleviates carbon tetrachlorideinduced acute liver injury via JNK-dependent mechanism in mice. World J. Gastroenterol. 21, 5473. doi:10.3748/wjg.v21.i18.5473

Yin, H., Cheng, L., Agarwal, C., Agarwal, R., Ju, C., 2010. Lactoferrin protects against concanavalin A-induced liver injury in mice. Liver Int. 30, 623-632. doi:10.1111/j.1478-3231.2009.02199.x 
تأثير الكبد الوقائي لعقار "ديفرازيروكس" في نموذج تجريبي لإصابة الكبد الحادة الناجمة عن كونكانافالين-أ

\section{لل السادة الاكاترة}

ندى عادل حسن ، إيمان منطاوي، دعاء الثربيني، ابتهال الدمرداش

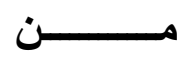

كلية الصيدلة، قسم الأدوية و السموم، جامعة عين شمس، القاهرة، مصر

يشكل التهاب الكبد مشكلة صحية كبيرة في جميع أنحاء العالم، لأنه قد ينطور إلى تليف و سرطان للكبد.

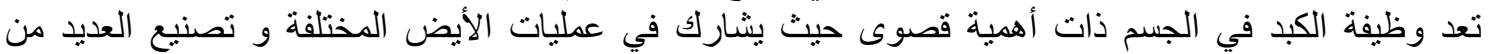

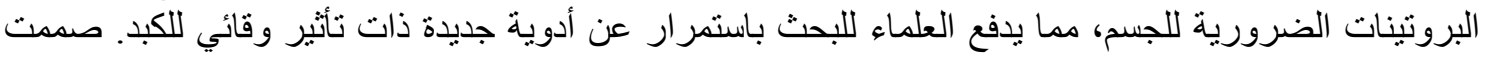

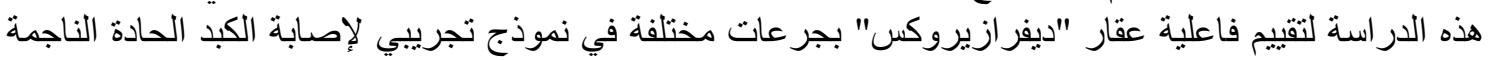

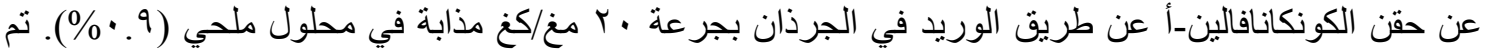

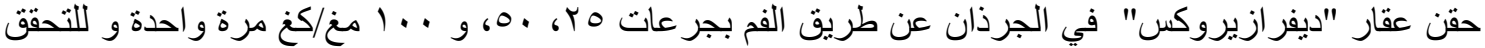

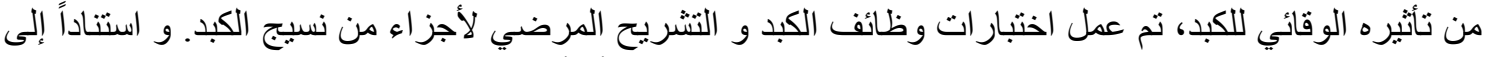

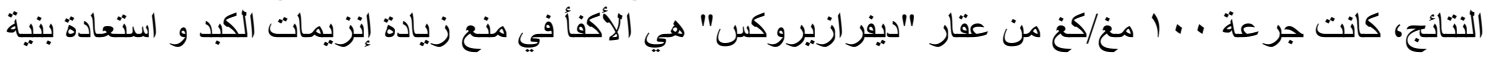

